\title{
Life Quality and Way of Life Style of Prototype of Sufficiency Economy at Dokbua Village, Phayao Province, Thailand
}

\author{
Sirichom Pichedboonkiat
}

\begin{abstract}
The purpose of this research were study the factors effected quality of life and way of life of agriculturist in economic village model. Research samples were agriculturist of 111 households. Research tools were questionnaire and interview. Statistics used for data analysis were frequency, percentage, mean, and standard deviation. Research results were the way of life and quality of life of agriculturist in economic village model, DokBua village. There are 215 households with population of 763 . The village is divided in 10 groups and governed by Ban Tun Sub-district Administrative Organization. The most of the villagers work such as make handicrafts. Villagers are promoted to work in a village which was the basketwork is used and for sale in a small group in a village and expand to other villages. Basket and coop are well-known and benefit products which are OTOP of Phayao. The factors effected for quality of life and way of life of agriculturist were villagers used land for planting rice and raising animals. Most of the villagers were informed about the philosophy of sufficiency economy via meeting so the villagers have adequate food from their organic farm. They live on a saving budget according to His Majesty King Bhumibol Adulyadej's philosophy of sufficiency economy that make them to save money and can pay for debt. They buy food from the local market and inform family member about budget planning Villagers are also do household account and can save money. For quality of life in Dok Bua village is a drug free village.
\end{abstract}

Index Terms-Quality of life, way of life style, sufficiency economy.

\section{INTRODUCTION}

Nowadays, the economic crisis in Thailand is effected many people especially the poor people who have difficulty of living. (Department of Provincial Administration, 1998:15). [1] There are also have many problem that effects people's quality of life such as less income and bad mental health. (Division of social, economic, and environmental development: (2000:19). [2] The effect of quality of life related to better life of the villagers. If villagers have good quality of life, that country will be developed. The policy committee realizes the villagers' better life by arranging local

Manuscript received October 9, 2016; revised November 10, 2016. This work was supported in part by the Office of the National Research Council of Thailand for research grant and would like to thank the savants from the Office of the National Research Council of Thailand for their suggestion and correction

S. Pichedboonkiat is with the Business Administrator and Liberal Art Faculty at Rajamanggala University of Technology Lanna, Chiang Rai Campus, Thailand (e-mail: sirichom12@gmial.com). economy and society development plan in order to achieving goal by applying the concept of sufficiency economy according to His Majesty King Bhumibol Adulyadej's philosophy (Department of Provincial Administration, 1998:3-8) [3] "Government supports living rely on oneself that relevant to country development strategy and economy and economy and society nation development number 11 which have a goal for solving poor problem and increase people's quality of life according to the philosophy of sufficiency economy by focusing on economy in a society. (Office of the National economic and social development, 2006:4). [4] According to His Majesty King Bhumibol Adulyadej's philosophy of sufficiency economy which supports a better life quality. DokBua village number 4 is located in Ban Tun Sub-district, Muang District, Phayao Province. Most of the villagers are agriculturist such as farmer, gardener, and farm.

The effect from the economic crisis such as the villagers were in debt, high competition for social and economic, and products were uninterested. Due to many problem effected, the community leader convinces the villagers to solve the problem with living by sufficiency economy in order to have a better quality of life. According to The King of Thailand's philosophy of sufficiency economy highlights a balanced way of living. Three principles moderation, reasonableness, and self-immunity along with the conditions of morality and knowledge can be applied to any level of the society from an individual to a country. This article proposes that the philosophy of sufficiency economy conveys new theory in addressing current development challenges, which are issues of institutions, human capital, environmental sustainability and the role of government. The philosophy of sufficiency economy, as a new paradigm of development, aims at improving human well-being as a development goal.

Therefore, the researcher conducted the research about the way of living by sufficiency economy of economic village model in Dok Bua village number 4 Ban Tun Sub-district, Muang District, and Phayao Province in order to know the way to develop as well as to expand to the other community.

\section{METHODS}

This research is a qualitative research and participatory research consisting of following procedure:

Research population was all agriculturists in Dok Bua village Number 4, Ban Tun Sub-district, Muang District, Phayao Province which is divided into 10 groups with 215 household. 
Research sample was agriculturists from stratified random sampling with 111 household. The researcher chose the village which was Dok Bua Village Number 4, Ban Tun Sub-district, Muang District, Phayao Province because this village won the prize for sufficiency economy village on 2012. The researcher divides the houses into 10 groups. Stratums all groups in Dok Bua village number 4, Ban Tun Sub-district, Muang district, Phayao Province which were: Set 1 Ruam jai phatana, Set 2 Rim tan tong, Set 3 Vitee por piang, Set 4 Rajaphuek, Set 5 Tam roi phor, Set 6 Ruam jai phatana 2, Set 7 Tam roi phor 2, Set 8 Rajaphuek 2, Set 9 Vitee por piang 2, Set 10 Rim tan tong 2.

The researcher random agriculturist and family member in Dok Bua with $50 \%$.

Research tools which close ended questions and open ended questions were used for research tools with 4 parts of questions.

1) Personal background such as age, sex, education background, number of family member, budget, and knowledge about the philosophy of Economic village model.

2) Way of living according to sufficient economy such as agricultural land preparation, purpose of using land, realize about sufficiency economic living, daily spending, saving. A successful factor for sufficiency economy's way of living such as using land for agricultural area, production process, agricultural products, knowledge about sufficiency economy's way of living, living on sufficiency economy based, expenditure, and agricultural budget.

3) I nformation about the quality of life. Information about the quality of life such as health and mental health which use the questionnaire from Department of mental health, Ministry of Public Health.

4) Information about problem and suggestion for living on sufficiency economy based.

After that analyze data then summarize about a successful of agriculturist in Dok Bua village for economic village model, village number 4, Ban Tun Sub-district, Muang District, Phayao Province.

\section{A. Data Collecting}

1) Primary data

Data was collected from agriculturists and 111 member samples by using the questionnaire which contained close-ended questions and open-ended questions

2) Secondary data

Data was collect by reading books, research articles, journals, publication, relevant document, internet, government center, relevant department, and research.

\section{A. Data Analysis}

Checked data validity then analyzed data by using statistics in order to figure out the answer for research objectives. The statistic used for research objective all items were percentage, mean, standard deviation, and content analysis with explanation. Then presented and published to the other villages in a form of VCD.

\section{RESUltS AND DISCUSSIONS}

Way of life and quality of life of agriculturist in economic village model, Dok Bua village, village number 4, Ban Tun Sub-district, Muang District, Phayao Province. A study of the economy of Dok Bua village, Ban Tun Sub-district, Muang District, Phayao Province was to study the background of economy and society in Dok Bua village. It was descriptive analysis and SWOT analysis about the community economy development. Background of Dok Bua village is located near mountain and river which has natural landscape. There are 215 households with population of 763,379 men and 384 women. Northern Thai language is used for communication. The village is divided in 10 groups and governed by Ban Tun Sub-district Administrative Organization. $80 \%$ of the villagers work such as $16 \%$ make handicrafts and $4 \%$ do different job. Villagers are promoted to work in a village. The basketwork is used and for sale in a small group in a village and expand to other villages. Basket and coop are well-known and benefit products which are OTOP of Phayao. Villagers worked together and helped each other which created community strength that villagers had extra income as well as preserved cultural heritage for younger generation. Some villagers might cooperated with the villagers in the other village such as water hyacinth wickerwork.

\section{A. Potential of the Economy of Dok Bua Village Analysis Strength}

1) Used material in the village which saved cost.

2) Villagers had skills of local wisdom products which had good quality .

3) There was product distribution center which the villagers could sell their products and they could avoid the intermediary.

4) Arranged the meeting to discuss about problem and opinion.

5) Villagers worked together and helped each other which made village to develop.

6) Had budget for effective project.

B. Weak

1) Did not have product development for high competition market.

2) Product process slowly which due to delicate handwork.

3) Low cost production which had small amount of profit

4) Some products were not well known.

5) Did not advertise so the products were not well known

6) Some villagers spent useless loan money which caused debt.

\section{Opportunity}

1) The village was supported by a government so villagers could work

2) Dok Bua village received twice trophy awards from His Majesty King Bhumibol Adulyadej for sufficiency economy village. There was a learning center in a village where people could visit.

3) Arranged provincial and national product exhibition for people to know about the village.

4) A campaign of the organization promoted one village one product that made well known products.

5) Arranged the meeting, training, or visiting so the 
villagers would know how to develop well known products.

\section{Treat}

1) High market competition of the similar product.

2) Political problem which made OTOP product uninteresting.

3) Economic crisis caused costly products.

4) Modern technology caused younger generation did not realize about sufficiency economy's way of living.

5) Factors effected quality of life and way of life of agriculturist in economic village model, Dok Bua village number 1, Ban Tun Sub-district, Muang District, and Phayao Province. Villagers used land for planting rice and raising animals. Most of the villagers were informed about the philosophy of sufficiency economy via meeting so the villagers have adequate food from their organic farm. They live on a saving budget according to His Majesty King Bhumibol Adulyadej's philosophy of sufficiency economy that make them to save money and can pay for debt. They buy food from the local market and inform family member about budget planning. There is a bank for agriculture which is used for agricultural loan. Villagers are also do household account and can save money. For quality of life in Dok Bua village is a drug free village.

6) A successful lesson for way of life and quality of life developing of agriculturist in economic village model, Dok Bua village. A factor which makes Dok Bua village to success for economic village model is social budget and administrative management which are:

The community administrator and leader promote about the living that based on philosophy of sufficiency economy. The admiration of a community leader who is a village chief of village number 4. He convinced people to live on philosophy of sufficiency economy, work hard, and to devote. The collaboration of administrator, staff, Ban Tun Sub-district Administrative Organization, and villager to live on the philosophy of sufficiency economy. Continuing process such as arrange the meeting every month for problem and problem solving discussion that effect quality of life of the villagers in Dok Bua village.

7) Problem for agriculturists who live in economic village model, Dok Bua village, village number 4, Ban Tun. Sub-district, Muang District, Phayao Province. Problem in Dok Bua village are summarized as follows:

Some villagers do not understand and do not accept how to live on the philosophy of sufficiency economy by using resources in the village such as gas dung or bio-fertilizer for planting.Climate unstable which effects cultivation. Suggestions for economic development in Dok Bua village New product development. Market promoting development so people will know the products. Every household member realize about sufficiency economy. Arrange the training that the villagers would aware of economic and social problem in Thailand then they will work together and help each other.

\section{E. Study Limitation}

1) Villagers were not available due to their personal issues, climate change, local tradition, natural disaster such as windstorm and earthquake so the questionnaires were done in the evening, by appointment, and Buddhist day.

2) Some villagers did not demonstrate the process because it took time to prepare the equipment.

3) There was no figure of number which caused inaccuracy.

4) Some informants did not provide all information which cause to ask Local Government Organization.

\section{CONCLUSIONS}

Factors effected quality of life and way of life of agriculturist in economic village model, Dok Bua village number 1, Ban Tun Sub-district, Muang District, Phayao Province. Villagers used land for planting rice and raising animals. Most of the villagers were informed about the philosophy of sufficiency economy via meeting so the villagers have adequate food from their organic farm. They live on a saving budget according to His Majesty King Bhumibol Adulyadej's philosophy of sufficiency economy that make them to save money and can pay for debt. They buy food from the local market and inform family member about budget planning. There is a bank for agriculture which is used for agricultural loan. Villagers are also do household account and can save money. This reason had shown that the strength of Thai Nation has been nurtured and developed by His Majesty King Bhumibol Adulyadej, who is the soul of the nation. Through his caring leadership, His Majesty has earned the abiding love and profound respect of his people, and through his thinking he has laid the foundation for and inspired his country's development strategy. His Majesty's philosophy of "Sufficiency Economy" lies at the heart of Thailand's development thinking, and indeed it can serve as guidance for the country's economic and social developments. For quality of life in Dok Bua village is a drug free village which was relevant to the research of Anan Ananthakul (1998) [6] considered the Philosophy of Sufficiency Economy as a basis for political development of the country, due to its encouragement of people participation along the process of development. In addition, the philosophy also emphasizes geopolitics, sustainable development, community empowerment, and social capital development and as well as good governance.

Villagers in Dok Bua village lived on sufficiency economy due to Thais royal to nation, religion, and king, especially His Majesty King Bhumibol Adulyadej who was the model of living on sufficiency economy based on careful and had sufficiency life which was relevant to the research of Surakiate Setreethai (2000) [7] who stated that sufficiency economy based on human, social, and economy development. It also relevant to Prawet Wasri (1999) explained that the Philosophy of Sufficiency Economy was a middle-path development strategy, which interconnected all related factors in a holistic way. Thus it can be used for revitalizing the socio-economy, which had been under the 1997 crisis and imbalance development strategy over the past decades. The Philosophy of Sufficiency Economy stated the 7 sufficiency items as follows:

1) Sufficient for everybody, every families, and do not leave.

2) Sufficient mind with kindness and sacrifice. 
3) Sufficient environment with preserve environment for working such as integrated agriculture.

4) Sufficient community with collaboration that could solve all problems.

5) Sufficient talent that learn to adapt.

6) Sufficient culture with suitable culture and environment.

7) Sufficient life for good mental health.

This research have shown that the Philosophy of Sufficiency Economy calls for a balanced and sustainable development at all levels. As a practical example of applying the philosophy of Sufficiency Economy, His Majesty the King has developed systematic guidelines for proper management of land and water resources, based on His experiments with integrated agriculture over the years. 3 This system of agriculture is commonly known in Thailand as New Theory Agriculture, which is also regarded as a new sustainable agriculture towards self-reliance for the rural household. The main purpose of the New Theory Agriculture is to make farmers more self-reliant through a holistic management of their land, while living harmoniously with nature and within society. The complete New Theory Agriculture has three stages: (1) sufficiency at the household level, (2) sufficiency at the community level, and (3) sufficiency at the national level.

In sum, Sufficiency Economy is a holistic concept of moderation and contentment. It sets out to shield the people and the country from adverse shocks, and acknowledges interdependency among people at all levels as an approach, against the backdrop of interdependence and globalization. It emphasizes the use of knowledge wisely with due consideration. Its values include integrity, diligence, harmlessness and sharing. Finally, it seeks to achieve balance and sustainability.

Suggestion for further research:

1) Should study of stakeholder both in Thailand and overseas to transfer the knowledge and apply the philosophy of sufficiency economic for living.

2) Should study of the evaluation and compare projects that was not relate to sufficiency economic and the other projects that do not relevant to sufficiency economic.

3) Should study about network of improve quality of life with every type of work.

4) Should study about sufficiency economic for youth in all educational institutes.

\section{ACKNOWLEDGMENT}

The researcher would like to express sincere thanks to the Office of the National Research Council of Thailand for research grant and would like to thank the savants from the Office of the National Research Council of Thailand for their suggestion and correction.

The researcher would also thank Mr. Ban Boongum, Head of village number 4, Dok Bua village, Muang District, Phayao Province for suggestion and help with research process.

Additionally, the researcher would like to thank the village leader and all villagers in village number 4, Dok Bua village, Muang District, Phayao Province for data collecting

Finally, the researcher would like to thank lecturers, students in Rajamangala University of Technology Lanna Chiang Rai for their help and support.

\section{REFERENCES}

[1] A. Sananarong, Economy Self-Reliance: Concept and Strategy, Bangkok: Local Press, Department of Provincial Administration, 1998.

[2] S. Prasitratsin, JPT 2 Basic Information of Household Evaluation Year 2003, Bangkok: Ministry of interior, 2000

[3] C. Chaiwisit, Philosophy of Sufficiency Economy, 1998.

[4] P. Fongsri, Social Indicator, Bangkok: Secretariat of Prime Minister Press, 2006.

[5] A. Ananthakul, Development Philosophy: New Theory by H.M. the King's Royal Initiative, in Jurisprudence and Political Dimension, Civil Services Training Institute, Special lecture.Bangkok, November. 1998.

[6] S. Setreethai, King's New Theory: Sufficiency Life, Bangkok: Community Press, 2000.

[7] P. Wasi, Economy and Civil Society as a Way to Regain Economic Society, Bangkok, 1989

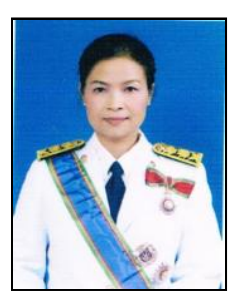

S. Pichedboonkiat was born in Thailand in 1964. She received her $\mathrm{Ph} . \mathrm{D}$. in development education and minor in rural development at Central Luzon State University, Philippines in year 2003.

She is an assist director of Academic Affairs and assist director of Research and Development. The current job is a director of Academic Affairs and Director of Clinic Technology at Rajamanggala University of Technology Lanna, ChiangRai campus, Thailand. Published articles are follows:

S. Pichedboonkiat, "Impact of learning and teaching management on cooperative education subject for undergraduate student at rajamangala university of technology, Lanna, Chiangrai." Presented at International Conference on the Social Sciences - Dubai 2016. February 27 - 29, 2016.

S. Pichedboonkiat, "Promoting of knowledge and moral lessons about the life's 38 blessings with video on the web based instruction," Presented at Distance Learning and Education (ICDLE 2014), Geneva, Switzerland, 0ctober 8-9, 2014.

S. Pichedboonkiat, "Development of prototype community for improve the quality of life of leprosy patient in Mealao Colony, Thailand , " Presented at International Conference on Psychological, Behavioral and Science - ICPBS 2014. Geneva, Switzerland, October 8-9, 2014.

S. Pichedboonkiat, "Development of potential productivity of elders through self-sufficiency economy, Thailand," Presented at the International Conference on Education and Social Sciences (INTCESS 2014), Istanbul Turkey, February 3-5, 2014.

S. Pichedboonkiat, "Development of web-based instruction on research proposal for undergraduate students at RMUTL, Thailand," Presented at the Third Asian Conference on Technology in the Classroom (ACTC 2013), Osaka, Japan, and April 25 - 28, 2013.

S. Pichedboonkiat, "The key performance indicator of the desirable characteristic of undergraduate student for stakeholder at Rajamangala University of Technology Lanna (RMUTL), Thailand," Presented at the International Conference on Economics and Social Science (ICESS 2013) Melbourne, Australia, Jan.20-21, 2013.

Research interest is based on integrated Education and Social Science.

Author's title: Associate Dr. Sirichom Pichedboonkiat. Memberships in professional societies are follows

She is a committee member of Upper Northern Research Administration Network and a member of The Association researchers. 